\title{
Ocena sztywności tętnic u chorych z przewlekłą chorobą nerek
}

\section{Arterial stiffness assessment in patients with chronic kidney disease}

\author{
Konrad Rekucki ${ }^{1}$, Marcin Madziarski ${ }^{2}$, Aleksandra Gajek ${ }^{2}$, \\ Agnieszka Sławuta ${ }^{3}$, Katarzyna Madziarska ${ }^{4}$ \\ ${ }^{1}$ Oddział Kardiologii Wojewódzkiego Centrum Medycznego w Opolu \\ ${ }^{2}$ Studenckie Koło Naukowe Uniwersytetu Medycznego we Wrocławiu \\ ${ }^{3}$ Oddział Kardiologii Szpitala ZOZ w Kłodzku \\ ${ }^{4}$ Katedra i Klinika Nefrologii i Medycyny Transplantacyjnej Uniwersytetu Medycznego Wrocław
}

\section{Streszczenie}

Choroby układu sercowo-naczyniowego są główną przyczyną zgonów u chorych na przewlekłą chorobę nerek. Współistnieją u nich klasyczne oraz specyficzne dla tej choroby czynniki ryzyka sercowo-naczyniowego.

Sztywność tętnic jest czynnikiem ryzyka, którego pomiar zyskuje na znaczeniu. Ultrasonograficzne badanie echo-tracking wysokiej rozdzielczości jest bezpośrednią i nieinwazyjną metodą oceny miejscowej sztywności tętnic. Pojawiają się kolejne doniesienia naukowe pokazujące, że oznaczane w tym badaniu parametry miejscowej sztywności tętnic, w tym wskaźnik sztywności beta, są niezależnymi czynnikami predykcyjnymi zgonu z powodów sercowo-naczyniowych. Ocena miejscowej sztywności tętnic może zająć ważne miejsce w ocenie ryzyka sercowo-naczyniowego ze względu na ograniczenia standardowych metod diagnostycznych występujące u pacjentów z przewlekłą chorobą nerek. W tym celu konieczne jest prowadzenie kolejnych badań nad zastosowaniem badania echo-tracking wysokiej rozdzielczości w tej grupie pacjentów. Słowa kluczowe: sztywność tętnic, echo-tracking, przewlekła choroba nerek

Folia Cardiologica 2018; 13, 2: 144-149

\section{Wstęp}

W ostatnich latach stopniowo się zwiększa rola pomiaru sztywności tętnic jako elementu oceny ryzyka sercowo-naczyniowego. Pomiar prędkości fali tętna (PWV, pulse wave velocity) znalazł zastosowanie w ustalaniu ryzyka sercowo-naczyniowego u pacjentów ze zdiagnozowanym nadciśnieniem tętniczym [1]. Inne metody oceny sztywności tętnic, takie jak ultrasonograficzne badanie markerów echo-tracking (eT) wysokiej rozdzielczości, są coraz częściej badane pod kątem przydatności u pacjentów obarczonych podwyższonym ryzykiem sercowo-naczyniowym. Jedną z grup chorych, u których pomiary sztywności tętnic mogłyby być pomocne, są chorzy z przewlekłą chorobą nerek (CKD, chronic kidney disease) [2, 3].

\section{Sztywność tętnic}

Sztywność jest jedną z właściwości tętnic wynikającą z budowy ściany naczynia, w szczególności ze stosunku włókien kolagenowych do elastycznych [2, 4]. Sztywność tętnic jest stosunkowo mniejsza w tętnicach sprężystych (elastycznych). Należą do nich: aorta, pień ramienno-głowowy, tętnice szyjne wspólne i wewnętrzne, tętnice 
podobojczykowe i tętnice biodrowe wspólne. Odgałęzienia tych tętnic to z kolei tętnice typu mięśniowego. Pełnią one funkcję naczyń oporowych w układzie tętniczym. Ich obecność umożliwia utrzymanie laminarnego przepływu przez obwodowe naczynia tętnicze, wbrew znacznym zmianom ciśnienia obserwowanym w zakresie tętnic centralnych. Z opisanej budowy tętnic proksymalnych i dystalnych wynika fizjologia przepływu krwi w organizmie człowieka. Skurcz lewej komory serca powoduje wyrzut pewnej objętości krwi do krążenia systemowego. Pojawienie się dodatkowej objętości krwi w aorcie wstępującej wywołuje jej rozciągnięcie, co jest możliwe dzięki jej wysokiej sprężystości. Rozkurcz ten przenosi się następnie na dalsze partie układu tętniczego, formując falę tętna. Fala tętna, dochodząc do naczyń oporowych, ulega odbiciu ze względu na wzrost sztywności tętnic. Fala odbita powraca do aorty wstępującej w rozkurczu, wspomagając perfuzję wieńcową. Ostateczny kształt fali tętna jest zatem wynikiem fali postępowej oraz fali odbitej.

\section{Sztywność tętnic - patofizjologia}

Zwiększenie sztywności tętnic, w szczególności aorty, prowadzi do skrócenia dystansu między sercem a miejscem powstawania fali odbitej, a także do zwiększenia prędkości fali tętna. Prowadzi to do wielu niekorzystnych następstw w układzie sercowo-naczyniowym. Dochodzi do skrócenia czasu, w którym fala odbita powraca do aorty wstępującej. Następuje to w późnym okresie skurczu, zamiast w rozkurczu. Wywołane tym obniżenie ciśnienia rozkurczowego krwi upośledza perfuzję wieńcową. Równocześnie wysokie centralne ciśnienie krwi prowadzi do wzrostu obciążenia następczego lewej komory w mechanizmie przeciążenia ciśnieniowego, a tym samym do przerostu lewej komory. Przerost mięśnia sercowego wraz z upośledzeniem przepływu wieńcowego sprzyjają niedokrwieniu mięśnia sercowego. Zwiększenie sztywności tętnic stanowi zatem element rozwoju między innymi nadciśnienia tętniczego, choroby niedokrwiennej serca oraz niewydolności serca.

\section{Etiologia zwiększenia sztywności tętnic}

Jest wiele przyczyn zwiększenia sztywności tętnic, najczęściej ocenianej poprzez pomiar PWV, co wynika z dostępności tej metody. Aortalną PWV determinują geny, wiek, zmiana stosunku włókien sprężystych do kolagenowych, ciśnienie skurczowe, ciśnienie tętna, spożycie sodu i kalcyfikacja naczyń. Dodatkowo do wzrostu sztywności tętnic przyczyniają się takie choroby, jak cukrzyca oraz CKD [5].

\section{Sztywność tętnic - metody pomiaru}

Istnieje wiele bezpośrednich nieinwazyjnych metod mogących posłużyć mierzeniu sztywności tętnic. Mogą one służyć ocenie regionalnej, miejscowej bądź systemowej sztywności tętnic [4]. Regionalną sztywność tętnic bada się, mierząc PWV między dwoma punktami w układzie tętniczym położonymi w różnej odległości od serca. Miejscowa sztywność tętnic jest mierzona w jednym miejscu i tym samym taki pomiar określa sztywność danej tętnicy w miejscu pomiaru. Pomiaru miejscowej sztywności tętnic dokonuje się za pomocą ultrasonografu $[4,6]$.

\section{Metody pomiaru regionalnej sztywności tętnic}

Aortalną PWV obecnie uznaje się za „złoty standard” w ocenie sztywności tętnic [4]. Wartość PWV ustala się, mierząc odstęp czasu między zarejestrowaniem fali tętna w dwóch różnych miejscach, najczęściej na prawej tętnicy szyjnej wspólnej i prawej tętnicy udowej. Odstęp ten jest uzyskiwany w formie graficznej, a do badania tętna nad tętnicami stosuje się takie metody, jak tonometria aplanacyjna, przetworniki mechaniczne czy ultrasonografia wysokiej rozdzielczości [7].

Prędkość fali tętna oblicza się ze wzoru: $P W V=D(w$ metrach $) / \Delta t$ ( w sekundach)

gdzie: D - dystans na powierzchni ciała między dwoma punktami pomiaru tętna, $\Delta t$ - czas między początkiem obu fal tętna $[4,7]$.

Fale tętna mogą być rejestrowane w dwóch punktach jednoczasowo bądź kolejno z ustaleniem $\Delta$ t w odniesieniu do załamka R w zapisie elektrokardiograficznym (EKG).

\section{Metody pomiaru miejscowej sztywności tętnic}

Podstawą badania eT wysokiej rozdzielczości jest inne podejście do oceny sztywności tętnic. Wskaźniki sztywności tętnic w tym badaniu są uzyskiwane poprzez ultrasonograficzną ocenę odkształcania tętnicy w jednym miejscu. W celu dokonania oceny tych parametrów konieczne jest uzyskanie wyraźnego obrazu ultrasonograficznego kompleksu intima-media zarówno przedniej, jak i tylnej ściany tętnicy szyjnej wspólnej w obrazowaniu podłużnym. Po zobrazowaniu tętnicy szyjnej wspólnej na obu ścianach tętnicy umiejscawia się znacznik ultrasonograficzny. Znacznik ten zmienia swoje położenie wraz ze zmianą położenia ścian tętnicy i tym samym umożliwia pomiar zmian średnicy tętnicy w czasie w odniesieniu do cyklu pracy serca zarejestrowanego za pomocą elektrokardiografu. Do wykonania pełnego badania konieczny jest również pomiar ciśnienia tętniczego, najczęściej wykonywany na tętnicy ramiennej. Pomiar ciśnienia tętniczego umożliwia obliczenie takich parametrów sztywności tętnic, jak: $\beta$ - beta, Ep - epsilon, AC - podatność naczyń, a także PWV $\beta$ - jednopunktową prędkość fali tętna. 
Wartości poszczególnych wskaźników są wyliczane automatycznie według poniższych równań [8]:

- $\beta$ - beta (wskaźnik sztywności beta):

$$
\beta=\ln (P s / P d) /[(D s-D d) / D d]
$$

gdzie: In - logarytm naturalny, Ps - ciśnienie skurczowe, Pd - ciśnienie rozkurczowe, Ds - średnica tętnicy w skurczu, Dd - średnica tętnicy w rozkurczu;

- Ep - epsilon (moduł Younga):

$$
E p=(P s-P d) /[(D s-D d) / D d]
$$

- AC (podatność naczynia) oblicza się na podstawie przekroju naczynia i ciśnienia tętniczego:

$$
A C=p(D s \times D s-D d \times D d) /[4 \times(P s-P d)]
$$

- PWVß (jednopunktowa prędkość fali tętna) oblicza się na podstawie opóźnienia między dwiema sąsiednimi falami opisującymi rozkurcz tętnicy z zastosowaniem wskaźnika sztywności $\beta$ :

$$
P W V \beta=\sqrt{ }(B * P / 2 * r)
$$

gdzie: $\mathrm{P}$ - ciśnienie rozkurczowe krwi, $r$ - gęstość krwi $\left(1,050 \mathrm{~kg} / \mathrm{m}^{3}\right)$.

Zgodnie ze stanowiskiem ekspertów Europejskiego Towarzystwa Kardiologicznego (ESC, European Society of Cardiology) uznaje się, że metody pomiaru miejscowej sztywności tętnic, takie jak eT wysokiej rozdzielczości, są przydatne w badaniach z zakresu patofizjologii i terapii bardziej niż w badaniach epidemiologicznych [4]. Ważną zaletą badania eT wysokiej rozdzielczości jest niezależność wskaźnika $\beta$ od zmian ciśnienia tętniczego [9]. Cecha ta może być jednym z powodów zwiększającej się liczby badań z udziałem pacjentów z podwyższoną sztywnością tętnic, które ukazują potencjalną kliniczną przydatność wskaźników miejscowej sztywności tętnic $[10,11]$. W ostatnich latach wzrosło również zainteresowanie wykorzystaniem eT wysokiej rozdzielczości u pacjentów z CKD [10-12].

\section{Przewlekła choroba nerek jako czynnik progresji chorób układu sercowo-naczyniowego}

Przewlekła choroba nerek jest powszechną chorobą dotykającą 10-16\% światowej populacji [13]. Aktualna definicja według wytycznych Kidney Disease: Improving Global Outcomes (KDIGO) stanowi, że są to utrzymujące się co najmniej 3 miesiące nieprawidłowości w budowie nerek lub zaburzenia czynności nerek mające znaczenie dla zdrowia [14]. W przebiegu naturalnym CKD dochodzi do stopniowego obniżenia współczynnika filtracji kłębuszkowej (GFR, glomerular filtration rate). Wraz ze spadkiem GFR wzrasta prawdopodobieństwo występowania nadciśnienia tętniczego [15]. Osoby z CKD charakteryzują się również zwiększoną tendencją do powstawania zaawansowanych zmian miażdżycowych [16]. Tym samym CKD z jednej strony zwiększa ryzyko wystąpienia chorób układu sercowo-naczyniowego (CVD, cardiovasvular disease) [13, 17], z drugiej zaś pogarsza rokowanie pacjentów już cierpiących na te choroby [14]. Znamienny jest fakt, że pacjenci z CKD są obarczeni wyższym ryzykiem zgonu z powodu CVD niż ryzyko progresji CKD do przewlekłej niewydolności nerek, a w konsekwencji - do schyłkowej niewydolności nerek $[5,18]$. Wymaga podkreślenia, że obecność klasycznych czynników ryzyka sercowo-naczyniowego, takich jak cukrzyca, nadciśnienie tętnicze, nikotynizm oraz dyslipidemia, nie tłumaczy w sposób wystarczający wyraźnego wzrostu ryzyka zgonu z powodu CVD u pacjentów z CKD [13, 14]. Innymi słowy, wśród tych pacjentów występują dodatkowe czynniki zwiększające ryzyko zgonu, które nie są obecne u pacjentów niechorujących na CKD i tym samym progresja choroby prowadzi do wzrostu globalnego ryzyka zgonu wraz ze wzrostem ryzyka zgonu z powodu CVD.

Przewlekła choroba nerek cechuje się licznymi zmianami patofizjologicznymi, spośród których część wiąże się ze wzrostem ryzyka zgonu spowodowanego CVD. Metaanaliza badań przeprowadzona przez Matsushitę i wsp. [13] wykazała, że spadek szacunkowego współczynnika filtracji kłębuszkowej (eGFR, estimated glomerular filtration rate) jest niezależnym czynnikiem prognostycznym globalnego ryzyka zgonu i zgonu z przyczyn sercowo-naczyniowych. W badaniu tym ryzyko zgonu jest stałe w zakresie eGFR 75-105 ml/min/1,73 $\mathrm{m}^{2}$ i zaczyna się zwiększać wraz ze spadkiem eGFR [13]. Wyniki te znajduja potwierdzenie w badaniu kohortowym przeprowadzonym w grupie ponad miliona pacjentów, w którym stwierdzono wyraźny wzrost globalnego ryzyka zgonu przy GFR poniżej $60 \mathrm{ml} /$ /min/1,73 $\mathrm{m}^{2}$. Wzrost wskaźnika albumina/kreatynina (ACR, albumin-to-creatinine ratio) do $10 \mathrm{mg} / \mathrm{g}$ i więcej również jest niezależnym czynnikiem rokowniczym zgonu i zgonu z przyczyn sercowo-naczyniowych [13]. Inne biochemiczne wskaźniki umożliwiające prognozowanie wzrostu ryzyka zgonu z powodu CVD to zwiększone stężenie cystatyny C [19] oraz fosforanów w surowicy [20]. W badaniach populacji chorych z CKD do oceny ryzyka sercowo-naczyniowego można wykorzystać również mniej typowe wskaźniki. Należy do nich sztywność tętnic (AS, arterial stiffness) mierzona jako PWV [3, 21] oraz inne wskaźniki sztywności tętnicy szyjnej wspólnej [2, 3].

\section{Sztywność tętnic w przewlekłej chorobie nerek}

Przewlekła choroba nerek jest chorobą, w której występuje wiele z wyżej opisanych nieprawidłowości skutkujących niekorzystnymi zmianami patofizjologicznymi. Już sam ten fakt powoduje, że u chorych na CKD ryzyko występowania zwiększonej sztywności tętnic jest podwyższone, a tym samym podwyższone jest ryzyko zachorowania na choroby, do których wzrost sztywności tętnic prowadzi. Jedną z istotnych nieprawidłowości są zmiany w gospodarce wapniowo-fosforanowej. Zaburzony metabolizm witaminy $\mathrm{D}_{3}$ prowadzi do obniżenia stężeń $25(\mathrm{OH}) \mathrm{D}_{3}$ i $1,25(\mathrm{OH})_{2} \mathrm{D}_{3}$ w surowicy. 
London i wsp. [22] dowiedli, że niskie stężenia tych związków korelują z podwyższoną sztywnością tętnic niezależnie od wieku i skurczowego ciśnienia tętniczego. Zaburzenia te skutkują obniżeniem gęstości mineralnej kości, co również wykazuje korelację z podwyższoną sztywnością tętnic [23].

\section{Wskaźnik sztywności beta jako czynnik predykcyjny zgonu z przyczyn sercowo-naczyniowych}

Shoji i wsp. [12] oceniali wskaźnik sztywności beta tętnicy szyjnej wspólnej (Caß, carotid artery $\beta$ ) i udowodnili, że zwiększenie miejscowej sztywności tętnic jest niezależnym czynnikiem ryzyka sercowo-naczyniowego w kohorcie 423 pacjentów poddawanych hemodializie. Wartość Caß okazała się czynnikiem ryzyka niezależnym od grubości kompleksu intima-media (IMT, intima-media thickness) oraz innych zmiennych [12]. Wartość Caß jako czynnika ryzyka znalazła również potwierdzenie w badaniu dotyczącym mniejszej kohorty pacjentów hemodializowanych. W grupie 80 osób wykazano podwyższone wartości Caß wśród pacjentów starszych oraz chorych na cukrzycę typu 2. U pacjentów z najwyższymi wartościami Caß globalne ryzyko zgonu było znamiennie wyższe niż u pacjentów z niższymi wartościami tego wskaźnika [11]. W innym badaniu w grupie pacjentów hemodializowanych wykazano wysoki poziom korelacji między Ep i Caß a PWV, które uważa się za „złoty standard” diagnostyczny w ocenie sztywności tętnic [10]. Autorzy badania sugerują tym samym, że ultrasonograficzne badanie eT wysokiej rozdzielczości jest wiarygodną metodą badawczą, która może stanowić dobrą alternatywę dla PWV. W badaniu tym stwierdzono również znacząco wyższe wartości Caß i Ep w grupie chorych na cukrzyce w porównaniu z grupą pacjentów bez cukrzycy. Udowodniono ponadto, że współczynnik sztywności $\beta$ jest znamiennie wyższy u pacjentów, którzy przebyli niemy udar mózgu uwidoczniony w badaniu rezonansu magnetycznego niż u pacjentów bez stwierdzonego udaru [24].

\section{Zastosowanie eT wysokiej rozdzielczości u pacjentów z przewlekłą chorobą nerek}

Obecnie PWV uważa się za „złoty standard” w ocenie sztywności tętnic. Mimo to badanie to ma pewne wady. Po pierwsze, w jego trakcie mogą wystąpić trudności z dokładnością zapisu fali tętna na tętnicy udowej, w szczególności u pacjentów z cukrzycą, otyłością, zespołem metabolicznym czy chorobą tętnic obwodowych. Po drugie, występowanie zwężeń w aorcie, tętnicach biodrowych czy udowych może osłabić lub opóźnić falę tętna. Dodatkowo dystans między oboma punktami pomiaru tętna powinien być mierzony jak najdokładniej, co jest bardzo trudne u pacjentów z otyłością brzuszną [4].
Badanie eT wysokiej rozdzielczości może pomóc pacjentom z CKD, którzy powszechnie cierpią na wymienione wyżej schorzenia, przede wszystkim zespół metaboliczny, chorobę tętnic obwodowych i cukrzycę. Pozwala ono na bezpośredni pomiar sztywności tętnic bez stosowania jakiegokolwiek modelu krążenia w celu obliczania pożądanych współczynników. Badanie eT umożliwia jednoczesne określenie wartości współczynników $\beta$, Ep, PWVb i AC z pomiarem IMT. Nie należy jednak zapominać o wadach tej metody. Ocena eT wymaga odpowiednich kwalifikacji osoby wykonującej badanie, a także jest zdecydowanie bardziej czasochłonna niż pomiar PWV [4]. Kolejne ograniczenie to niemożność odnoszenia sztywności aorty do sztywności tętnicy szyjnej wspólnej u chorych na cukrzycę lub z wysokim ciśnieniem tętniczym. Wynika to z faktu, że cukrzyca, nadciśnienie i inne czynniki ryzyka sercowo-naczyniowego wpływają na sztywność aorty w dużo większym stopniu niż na sztywność tętnicy szyjnej wspólnej [25].

\section{Rola pomiaru sztywności tętnic u pacjentów z przewlekłą chorobą nerek}

W badaniu Framingham zastosowanie PWV jako czynnika ryzyka wraz z innymi, standardowymi czynnikami ryzyka sercowo-naczyniowego poprawiło trafność oceny ryzyka [26]. Udowodniono również, że sztywność tętnic jest niezależnie powiązana z wyższym globalnym ryzykiem zgonu u pacjentów cierpiących na CKD w stopniach od 2. do 5. [3]. W tym samym badaniu wykazano również, że parametry miejscowej sztywności tętnic, a konkretnie średnica wewnętrzna tętnicy szyjnej, są związane ze zwiększonym globalnym ryzykiem zgonu. Wyniki te wskazują, że poszukiwanie dowodu na potencjalną prognostyczną wartość miejscowej sztywności tętnic w przewidywaniu ryzyka zgonu u pacjentów z CKD jest właściwym kierunkiem badań [2]. Pomiar miejscowej sztywności tętnic u chorych na CKD może mieć szczególną wartość ze względu na ograniczenia klasycznych metod diagnostycznych w tej grupie pacjentów, takich jak elektrokardiograficzna próba wysiłkowa czy echokardiografia $[14,27]$. U tych pacjentów rzadziej występują klasyczne objawy niedokrwienia mięśnia sercowego, stąd potrzeba poszukiwania nowych narzędzi służących poprawie oceny klinicznej. Uszkodzenie nerek ogranicza również możliwości zastosowania badań z wykorzystaniem środków kontrastowych - tomografii komputerowej i rezonansu magnetycznego [27]. W tej grupie mniejsza jest także wartość diagnostyczna laboratoryjnych wykładników funkcjonowania układu sercowo-naczyniowego, takich jak N-końcowy propeptyd natriuretyczny typu B (NT-proBNP) czy troponina sercowa [14].

Sztywność naczyń oraz ocena fali tętna znalazły szerokie zastosowanie w badaniach służących ocenie zmian hemodynamicznych w wielu stanach klinicznych. Przewlekła 
choroba nerek stanowi wyzwanie ze względu na złożoność procesów i czynników wpływających na ogólną kondycję pacjenta oraz zróżnicowanie populacji w zależności od zaawansowania upośledzenia funkcji filtracyjnej nerek. Wiadomo już, że poszczególne grupy pacjentów z CKD odnoszą różne korzyści z zastosowanych terapii. Dysponowanie nowoczesnym narzędziem, które pozwoliłoby na wyodrębnienie grupy obarczonej zwiększonym ryzykiem sercowo-naczyniowym wśród chorych o jeszcze umiarkowanie obniżonym GFR mogłoby zwiększyć skuteczność pierwotnej profilaktyki. 0 ile bowiem nie ulega wątpliwości, że chorzy z ciężkim upośledzeniem funkcji nerek są grupą o najwyższym ryzyku, o tyle niestety efekty terapii w tej grupie pozostają dalekie od ideału. Nawet zastosowanie takich metod, jak implantacja wszczepialnego kardiowertera-defibrylatora nie poprawia specjalnie rokowania, wobec średniej przeżywalności populacji z CKD na poziomie 18 miesięcy, co znacznie się różni od wyników u chorych z prawidłową funkcją nerek [28]. Podobnie trudne są decyzje dotyczące sposobu rewaskularyzacji z powodu ryzyka nasilenia nefropatii po zastosowaniu środka kontrastowego w czasie angioplastyki wieńcowej z jednej strony oraz z drugiej strony kilkukrotnie większej niż w populacji bez CKD śmiertelności okołooperacyjnej w CABG, zwłaszcza u chorych ze znacznie obniżonym eGFR [29].

\section{Podsumowanie}

U pacjentów chorujących na CKD obserwuje się nasilone niekorzystne zmiany w zakresie naczyń tętniczych, które dodatkowo się nasilają przy obniżaniu się GFR. Jednocześnie objawy podmiotowe i przedmiotowe CVD, takie jak ból dławicowy, charakteryzują się mniejszą czułością w tej grupie chorych. Większość badań wykorzystywanych w populacji ogólnej do diagnostyki i oceny ryzyka CVD - od elektrokardiograficznej próby wysiłkowej po koronarografię - napotyka na istotne ograniczenia u pacjentów z CKD. Tym samym istnieje wyraźne uzasadnienie dla poszukiwania nowych, dokładnych metod oceny stanu układu sercowo-naczyniowego u tych pacjentów, które powinny posłużyć zarówno prewencji, jak i wczesnemu wykrywaniu CVD w przebiegu CKD. Badanie eT wysokiej rozdzielczości może się stać pomocnym narzędziem w urzeczywistnieniu tego celu, ponieważ w świetle wyników badań $\beta$ oraz inne parametry miejscowej sztywności tętnic zyskały miano niezależnych czynników ryzyka sercowo-naczyniowego. Konieczne są jednak dalsze badania nad przydatnością tej metody.

\section{Konflikt interesów}

Autorzy nie zgłaszają konfliktu interesów.

\section{Abstract}

Cardiovascular diseases are the main cause of death among patients with chronic kidney disease. Classic and disease-specific cardiovascular risk factors are observed in this group of patients.

Recently, arterial stiffness has been paid more attention to as a cardiovascular risk factor. High-resolution echo-tracking is a direct and non-invasive ultrasound method of local arterial stiffness evaluation. New publications show that indices of local arterial stiffness, such as stiffness parameter beta, are predictors of cardiovascular mortality. Evaluation of local arterial stiffness can take a prominent place in cardiovascular risk assessment due to limitations of standard diagnostic methods present in chronic kidney disease. Further studies on high-resolution echo-tracking are essential to establish the role of this method in evaluation of chronic kidney disease patients.

Key words: arterial stiffness, echo-tracking, chronic kidney disease

Folia Cardiologica 2018; 13, 2: 144-149

\section{Piśmiennictwo}

1. Mancia G, Fagard R, Narkiewicz K, et al. Task Force for the Management of Arterial Hypertension of the European Society of Hypertension and the European Society of Cardiology, ESH/ESC Task Force for the Management of Arterial Hypertension, Task Force Members, Task Force for the management of arterial hypertension of the European Society of Hypertension, Task Force for the management of arterial hypertension of the European Society of Cardiology. 2013 ESH/ESC guidelines for the management of arterial hypertension: the Task Force for the Management of Arterial Hypertension of the European
Society of Hypertension (ESH) and of the European Society of Cardiology (ESC). Eur Heart J. 2013; 34(28): 2159-2219, doi: 10.1093/ /eurheartj/eht151, indexed in Pubmed: 23771844.

2. Blacher J, Safar ME, Pannier B, et al. Prognostic significance of arterial stiffness measurements in end-stage renal disease patients. Curr Opin Nephrol Hypertens. 2002; 11(6): 629-634, doi: 10.1097/01. mnh.0000040049.33359.2b, indexed in Pubmed: 12394609.

3. Karras A, Haymann JP, Bozec E, et al. Nephro Test Study Group. Large artery stiffening and remodeling are independently associated 
with all-cause mortality and cardiovascular events in chronic kidney disease. Hypertension. 2012; 60(6): 1451-1457, doi: 10.1161/HYPERTENSIONAHA.112.197210, indexed in Pubmed: 23090769.

4. Laurent S, Cockcroft J, Van Bortel L, et al. European Network for Non-invasive Investigation of Large Arteries. Expert consensus document on arterial stiffness: methodological issues and clinical applications. Eur Heart J. 2006; 27(21): 2588-2605, doi: 10.1093/eurheartj/ /ehl254, indexed in Pubmed: 17000623.

5. DeLoach SS, Townsend RR. Vascular stiffness: its measurement and significance for epidemiologic and outcome studies. Clin J Am Soc Nephrol. 2008; 3(1): 184-192, doi: 10.2215/CJN.03340807, indexed in Pubmed: 18178784.

6. Guerin AP, Blacher J, Pannier B, et al. Impact of aortic stiffness attenuation on survival of patients in end-stage renal failure. Circulation. 2001; 103(7): 987-992, indexed in Pubmed: 11181474.

7. Cieślik-Guerra U. Metody pomiaru sztywności tętnic. Nadciśnienie Tętnicze. 2011; 15: 42-48.

8. Jaroch J, Rzyczkowska B, Bociąga Z, et al. Relationship of carotid arterial functional and structural changes to left atrial volume in untreated hypertension. Acta Cardiol. 2016; 71(2): 227-233, doi: 10.2143/ /AC.71.2.3141854, indexed in Pubmed: 27090046.

9. Hirai T, Sasayama S, Kawasaki T, et al. Stiffness of systemic arteries in patients with myocardial infarction. A noninvasive method to predict severity of coronary atherosclerosis. Circulation. 1989; 80(1): 78-86, indexed in Pubmed: 2610739.

10. Yu ZX, Wang XZ, Guo RJ, et al. Comparison of ultrasound echo-tracking technology and pulse wave velocity for measuring carotid elasticity among hemodialysis patients. Hemodial Int. 2013; 17(1): 19-23, doi: 10.1111/j.1542-4758.2012.00707.x, indexed in Pubmed: 22620469.

11. Sato M, Ogawa T, Otsuka K, et al. Stiffness parameter $\beta$ as a predictor of the 4-year all-cause mortality of chronic hemodialysis patients. Clin Exp Nephrol. 2013; 17(2): 268-274, doi: 10.1007/s10157-012-0674-7, indexed in Pubmed: 23011291.

12. Shoji T, Maekawa K, Emoto M, et al. Arterial stiffness predicts cardiovascular death independent of arterial thickness in a cohort of hemodialysis patients. Atherosclerosis. 2010; 210(1): 145-149, doi: 10.1016/j. atherosclerosis.2009.11.013, indexed in Pubmed: 20022324.

13. Matsushita K, van der Velde M, Astor BC, et al. Chronic Kidney Disease Prognosis Consortium. Association of estimated glomerular filtration rate and albuminuria with all-cause and cardiovascular mortality in general population cohorts: a collaborative meta-analysis. Lancet. 2010; 375(9731): 2073-2081, doi: 10.1016/S0140-6736(10)60674-5, indexed in Pubmed: 20483451.

14. KGIGO 2012 Clinical Practice Guideline for the Evaluation and Management of Chronic Kidney Disease. Nephrol Dial. 2017; 19(1): 22-206, doi: 10.28996/1680-4422-2017-1-22-206.

15. Rao MV, Qiu Y, Wang C, et al. Hypertension and CKD: Kidney Early Evaluation Program (KEEP) and National Health and Nutrition Examination Survey (NHANES), 1999-2004. Am J Kidney Dis. 2008; 51(4 Suppl 2): S30-S37, doi: 10.1053/j.ajkd.2007.12.012, indexed in Pubmed: 18359406.

16. Yerkey MW, Kernis SJ, Franklin BA, et al. Renal dysfunction and acceleration of coronary disease. Heart. 2004; 90(8): 961-966, doi: 10.1136/hrt.2003.015503, indexed in Pubmed: 15253986.
17. Go AS, Chertow GM, Fan D, et al. Chronic kidney disease and the risks of death, cardiovascular events, and hospitalization. N Engl J Med. 2004; 351(13): 1296-1305, doi: 10.1056/NEJMoa041031, indexed in Pubmed: 15385656.

18. Keith DS, Nichols GA, Gullion CM, et al. Longitudinal follow-up and outcomes among a population with chronic kidney disease in a large managed care organization. Arch Intern Med. 2004; 164(6): 659-663, doi: 10.1001/archinte.164.6.659, indexed in Pubmed: 15037495.

19. Peralta CA, Katz R, Sarnak MJ, et al. Cystatin C identifies chronic kidney disease patients at higher risk for complications. J Am Soc Nephrol. 2011; 22(1): 147-155, doi: 10.1681/ASN.2010050483, indexed in Pubmed: 21164029.

20. Palmer SC, Hayen A, Macaskill P, et al. Serum levels of phosphorus, parathyroid hormone, and calcium and risks of death and cardiovascular disease in individuals with chronic kidney disease: a systematic review and meta-analysis. JAMA. 2011; 305(11): 1119-1127, doi: 10.1001/jama.2011.308, indexed in Pubmed: 21406649.

21. Guérin AP, Pannier B, Métivier F, et al. Assessment and significance of arterial stiffness in patients with chronic kidney disease. Curr Opin Nephrol Hypertens. 2008; 17(6): 635-641, indexed in Pubmed: 19031658.

22. London GM, Guérin AP, Verbeke FH, et al. Mineral metabolism and arterial functions in end-stage renal disease: potential role of 25-hydroxyvitamin D deficiency. J Am Soc Nephrol. 2007; 18(2): 613-620, doi: 10.1681/ASN.2006060573, indexed in Pubmed: 17202417.

23. Raggi $P$, Bellasi A, Ferramosca $E$, et al. Pulse wave velocity is inversely related to vertebral bone density in hemodialysis patients. Hypertension. 2007; 49(6): 1278-1284, doi: 10.1161/HYPERTENSIONAHA.107.086942, indexed in Pubmed: 17420331.

24. Ogawa T, Shimada M, Ishida H, et al. Relation of stiffness parameter beta to carotid arteriosclerosis and silent cerebral infarction in patients on chronic hemodialysis. Int Urol Nephrol. 2009; 41(3): 739-745, doi: 10.1007/s11255-009-9526-0, indexed in Pubmed: 19184511.

25. Paini A, Boutouyrie P, Calvet D, et al. Carotid and aortic stiffness: determinants of discrepancies. Hypertension. 2006; 47(3): 371-376, doi: 10.1161/01.HYP.0000202052.25238.68, indexed in Pubmed: 16446398.

26. Mitchell GF, Hwang SJ, Larson MG, et al. Arterial stiffness and cardiovascular events: the Framingham Heart Study. Circulation. 2010; 121(4): 505-511, doi: 10.1161/CIRCULATIONAHA.109.886655, indexed in Pubmed: 20083680.

27. Herzog CA, Asinger RW, Berger AK, et al. Cardiovascular disease in chronic kidney disease. A clinical update from Kidney Disease: Improving Global Outcomes (KDIG0). Kidney Int. 2011; 80(6): 572-586, doi: 10.1038/ki.2011.223, indexed in Pubmed: 21750584.

28. US Renal Data System. USRDS 2010 Annual Data Report: Atlas of Chronic Kidney Disease \& End-Stage Renal Disease in the United States. National Institutes of Health, National Institute of Diabetes and Digestive and Kidney Diseases, Bethesda 2010.

29. Charytan DM, Kuntz RE. Risks of coronary artery bypass surgery in dialysis-dependent patients - analysis of the 2001 National Inpatient Sample. Nephrol Dial Transplant. 2007; 22(6): 1665-1671, doi: 10.1093/ndt/gfl835, indexed in Pubmed: 17299001. 